U.S. Department of Commerce, Bureau of Standards

RESEARCH PAPER RP590

Part of Bureau of Standards Journal of Research, Vol. 11, August 1933

\title{
THERMAL EXPANSION OF COLUMBIUM
}

\author{
By Peter Hidnert and H. S. Krider
}

\section{ABSTRACT}

This paper gives the results of an investigation on the linear thermal expansion of a rod of columbium containing 0.93 percent tin and 0.26 percent iron. Data were obtained at various temperatures between $-135^{\circ}$ and $+305^{\circ} \mathrm{C}$. The following equation is given as the most probable second-degree equation for the expansion of this rod of columbium:

$$
L_{\mathrm{t}}=L_{\mathrm{o}}\left[1+\left(7.06 t+0.00144 t^{2}\right) 10^{-6}\right]
$$

The coefficient of expansion increases regularly with temperature. From $0^{\circ}$ to $100^{\circ} \mathrm{C}$. the average coefficient of expansion is $7.2 \times 10^{-6}$ per ${ }^{\circ} \mathrm{C}$. Table 3 gives coefficients of expansion for various temperature ranges.

\section{CONTENTS}

I. Introduction

II. Material investigated

III. Apparatus . .

IV. Results

\section{INTRODUCTION}

In 1801 Charles Hatchett ${ }^{1}$ analyzed a small specimen of a darkcolored heavy ore which had been sent by Mr. Winthrop, of Massachusetts, to Sir Hans Sloane, of England. This analysis lead Hatchett to the discovery of a new metallic element which he named "columbium." It has also been known as "niobium."

In 1929 Balke ${ }^{2}$ described the preparation of columbium, which had been produced in appreciable quantities only during the past few years. He stated that nearly all of the physical properties of columbium were yet to be determined.

A rod of columbium $4.6 \mathrm{~mm}$ in diameter was received from the Fansteel Products Co., Inc., North Chicago, Ill., several months ago for an investigation of the linear thermal expansion of this metal, for there are no available data on the thermal expansion of columbium. This paper gives results obtained on the linear thermal expansion of the rod of columbium at various temperatures between $-135^{\circ}$ and $+305^{\circ} \mathrm{C}$.

The authors wish to express their appreciation for the cooperation by the Fansteel Products Co. that furnished the rod of columbium and information about its preparation. Acknowledgment is due to H. W. Bearce, W. Souder, and H. D. Hubbard, of the Bureau of Standards, for valuable suggestions.

\footnotetext{
${ }^{1}$ Hatchett, An Analysis of a Mineral Substance from North America, containing a metal hitherto unknown, Phil. Trans. Royal Soc. London, pt. 1, p. 49, 1802.

2 Balke, Metals of the Tungsten and Tantalum Groups, Ind. and Eng. Chem., vol. 21, p. 1002, 1929. This paper also indicates the applications of columbium.
} 


\section{MATERIAL INVESTIGATED}

The sample of columbium was prepared as follows:

Columbium powder was pressed into a bar $5 / 8$ inch square and 16 inches long which was heat treated by its own resistance in a vacuum electric furnace for a number of hours until the metal was thoroughly degassed. This bar was then hammered to compact the metal and given a second treatment in a vacuum furnace. The bar was then swaged round and given a third heating in the vacuum furnace. In each case these heats were carried to a point as close to the melting point of the metal as possible. After the third heating the rod was swaged to 0.18 inch (or $4.6 \mathrm{~mm}$ ) diameter. Therefore, as received, the rod represented columbium slightly strain hardened after its last heating.

A piece cut from the rod was analyzed ${ }^{3}$ and found to contain tin 0.93 percent and iron 0.26 percent. Titanium and tungsten were not detected.

Fine filings from the rod of columbium were sifted through 200mesh bolting cloth and annealed in vacuo at $400^{\circ} \mathrm{C}$. for $2 \frac{1}{2}$ hours. The annealed powder was loaded into a small capillary glass tube with a portion of spectroscopically pure sodium chloride. An X-ray spectrogram of the sample was then taken ${ }^{4}$ with molybdenum $K \alpha$ radiation from a water cooled Coolidge type X-ray tube. The crystal lattice structure of the annealed columbium proved to be that of a body-centered cube with the cube edge having a length of $3.293 \pm 0.002 \mathrm{~A}$. The following table gives a comparison of available results on the crystal structure of columbium.

\section{TABLE 1.-Crystal structure of columbium}

\begin{tabular}{|c|c|c|c|}
\hline Observer & Date & Type of crystal structure & $\begin{array}{l}\text { Length } \\
\text { of edge } \\
\text { of cube }\end{array}$ \\
\hline $\begin{array}{l}\text { Olshausen }{ }^{a} \\
\text { McLennan and Monkman }{ }^{b} \\
\text { Meisel }{ }^{c} \\
\text { Neuburger }{ }^{d} \\
\text { Kennedy }\end{array}$ & $\begin{array}{l}1925 \\
1929 \\
1930 \\
1931 \\
1933\end{array}$ & \begin{tabular}{|l} 
Face-centered cubic \\
Body-centered cubic
\end{tabular} & $\begin{array}{c}\times 10^{-8} \mathrm{~cm} \\
4.191 \\
3.291 \\
3.31 \\
3.303 \\
3.293\end{array}$ \\
\hline
\end{tabular}

a Olshausen, Z. Krist., vol. 61, p. 463, 1925. Sample contained about 3 percent aluminum by weight (density 7.5).

$b$ McLennan and Monkman, Trans. Roy. Soc. Canada III, vol. 23, p. 255, 1929. Sample contained tantalum.

c Meisel, Z. Anorg. Chem., vol. 190, p. 237, 1930. Samples about 99 percent pure. Density of 1 sample 8.55 .

d Neuburger, Z. Anorg. Chem., vol. 197, p. 219, 1931. Calculated density 8.56.

- See p. 280.

The density calculated from X-ray measurements $(a=3.293 \mathrm{~A})$ is 8.62. After the expansion tests, the density ${ }^{5}$ of the sample used in the expansion determinations was found to be $8.572 \mathrm{~g} / \mathrm{cm}^{3}$ at $24^{\circ} \mathrm{C}$.

\section{APPARATUS}

The apparatus described in Bureau of Standards Scientific Paper No. 410 was used for the determinations of linear thermal expansion.

3 By J. A. Scherrer, of the Chemistry Division of this Bureau.

4 By R. G. Kennedy, of this Bureau.

5 Determined by E. L. Peffer, of this Bureau. 


\section{RESULTS}

A sample $300 \mathrm{~mm}$ long was cut from the rod of columbium described in section II. As this metal begins to oxidize ${ }^{6}$ at about $400^{\circ} \mathrm{C}$. when heated in air, the maximum temperature of the expansion determinations was maintained below this temperature.

Figure 1 shows the observations obtained on the linear thermal expansion of this sample on heating and cooling in six tests. The expansion curves are plotted from different origins in order to show

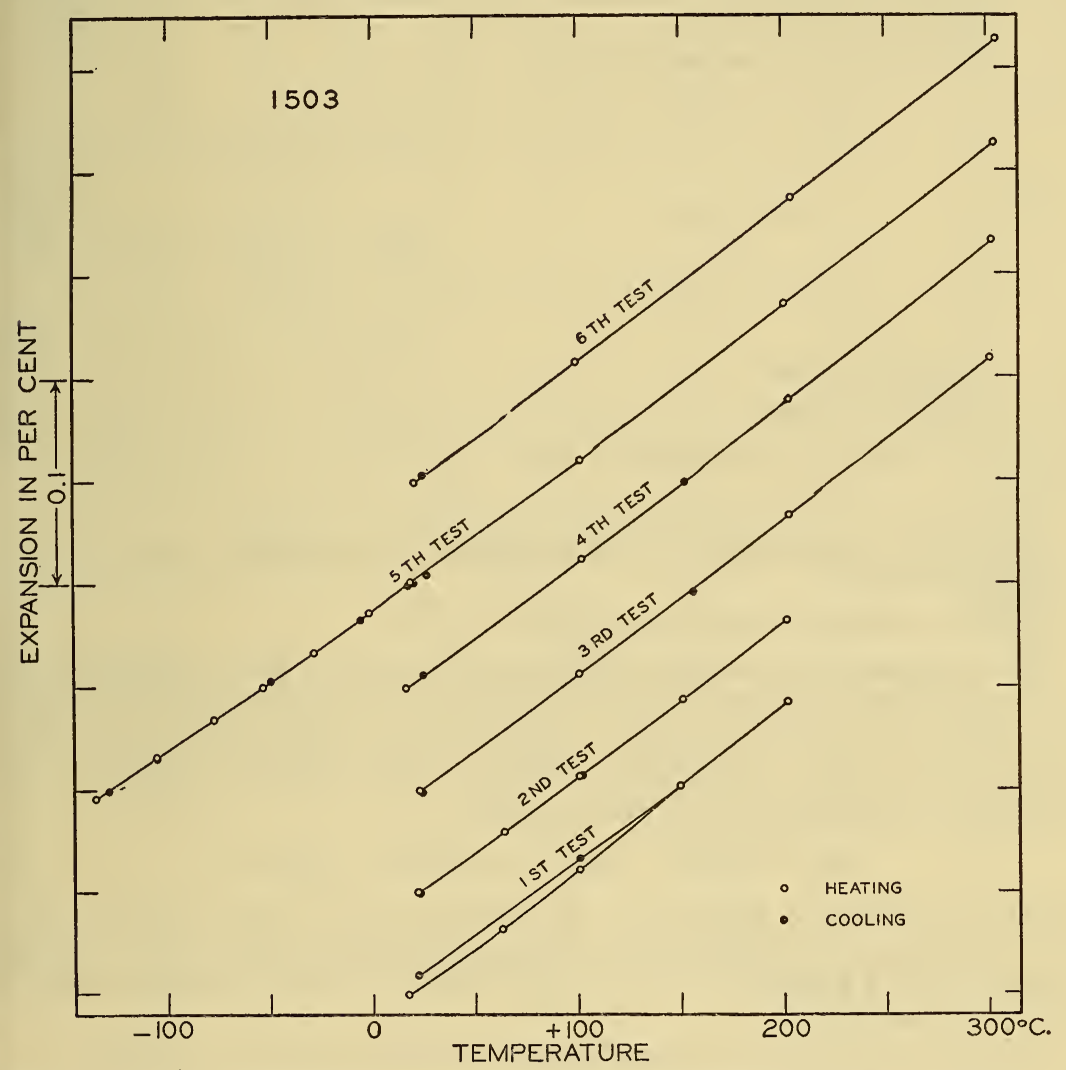

FIGURE 1.-Linear thermal expansion of columbium containing 0.93 percent tin and 0.26 percent iron.

the individual characteristics of each curve. In the first test, the observations on cooling lie below the expansion curve on heating, but in the following tests the observations on cooling are much closer to the corresponding expansion curves. The heat treatment incident to the first test probably annealed the sample.

Table 2 gives average coefficients of linear expansion which were obtained from the expansion curves shown in figure 1 . The last column in the table shows the difference in length before and after each expansion test. The plus $(t)$ sign indicates an increase in length and the minus $(-)$ sign a decrease in length. 
TABLE 2.-Average coefficients of linear expansion of columbium

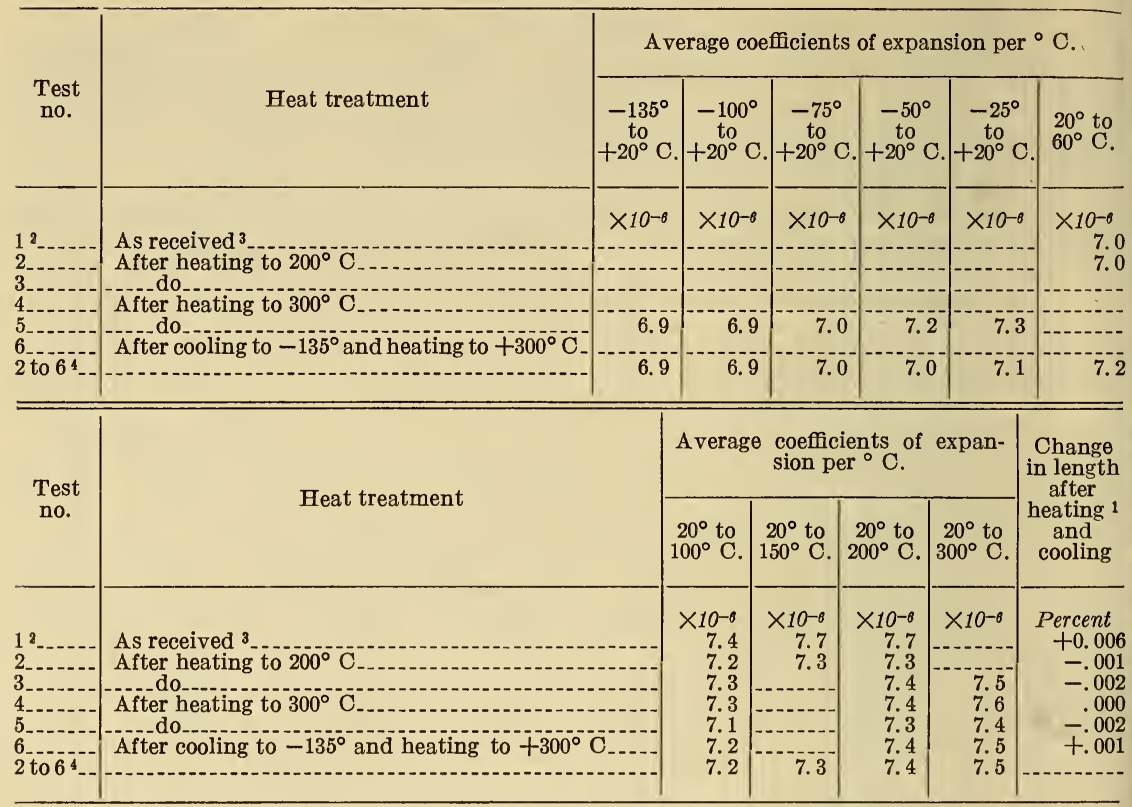

1 To about $200^{\circ} \mathrm{C}$. for tests 1 and 2 and to about $300^{\circ} \mathrm{C}$. for tests 3 to 6 , inclusive

2 On cooling, the average coefficient of contraction is $7.4 \times 10^{-6}$ between $200^{\circ}$ and $20^{\circ} \mathrm{C}$. and $7.3 \times 10^{-6}$ between $100^{\circ}$ and $20^{\circ} \mathrm{C}$.

3 See p. 280.

4 Coefficients of expansion computed from equation (1) on p. 282.

The coefficients of expansion obtained in tests 2 to 6 , inclusive, may be considered applicable for heat-treated or annealed columbium. From all of the observations obtained on heating between $-135^{\circ}$ and $+305^{\circ} \mathrm{C}$. in tests 2 to 6 , inclusive, the following equation was derived by the method of least squares:

$$
\Delta L=L\left[7.12(t-20)+0.00144(t-20)^{2}\right] 10^{-6}
$$

In this equation $L$ represents the length of the metal at $20^{\circ} \dot{\mathrm{C}}$. and $\Delta L$ represents the expansion or change in length from $20^{\circ} \mathrm{C}$. to any temperature $t$ between $-135^{\circ}$ and $+305^{\circ} \mathrm{C}$. The probable error of $\Delta L$ is $\pm 0.000006 L$.

Equation (1) may be transformed into the following equation

$$
L_{t}=L_{o}\left[1+\left(7.06 t+0.00144 t^{2}\right) 10^{-6}\right]
$$

where $L_{o}$ represents the length of the metal at $0^{\circ} \mathrm{C}$. and $L_{t}$ the length at any temperature $t$ between $-135^{\circ}$ and $+305^{\circ} \mathrm{C}$.

The expansion curve represented by equation (2) is shown in figure 2. The observations obtained on heating in tests 2 to 6 , inclusive (reduced to an initial temperature of $0^{\circ}$ C.), are included. The numbers near the observations indicate the tests.

The average coefficients of expansion for various temperature ranges given in table 3 were computed from equation (2). These coefficients of expansion are approximately 10 percent larger than the coefficients of tantalum, ${ }^{7}$ a similar metal that also belongs to subgroup V A (vanadium, columbium, tantalum, and uranium).

\footnotetext{
7 Hidnert, B.S.Jour. Research, vol. 2 (RP62), p. 887, May 1929.
} 
EXPANSION IN PERCENT

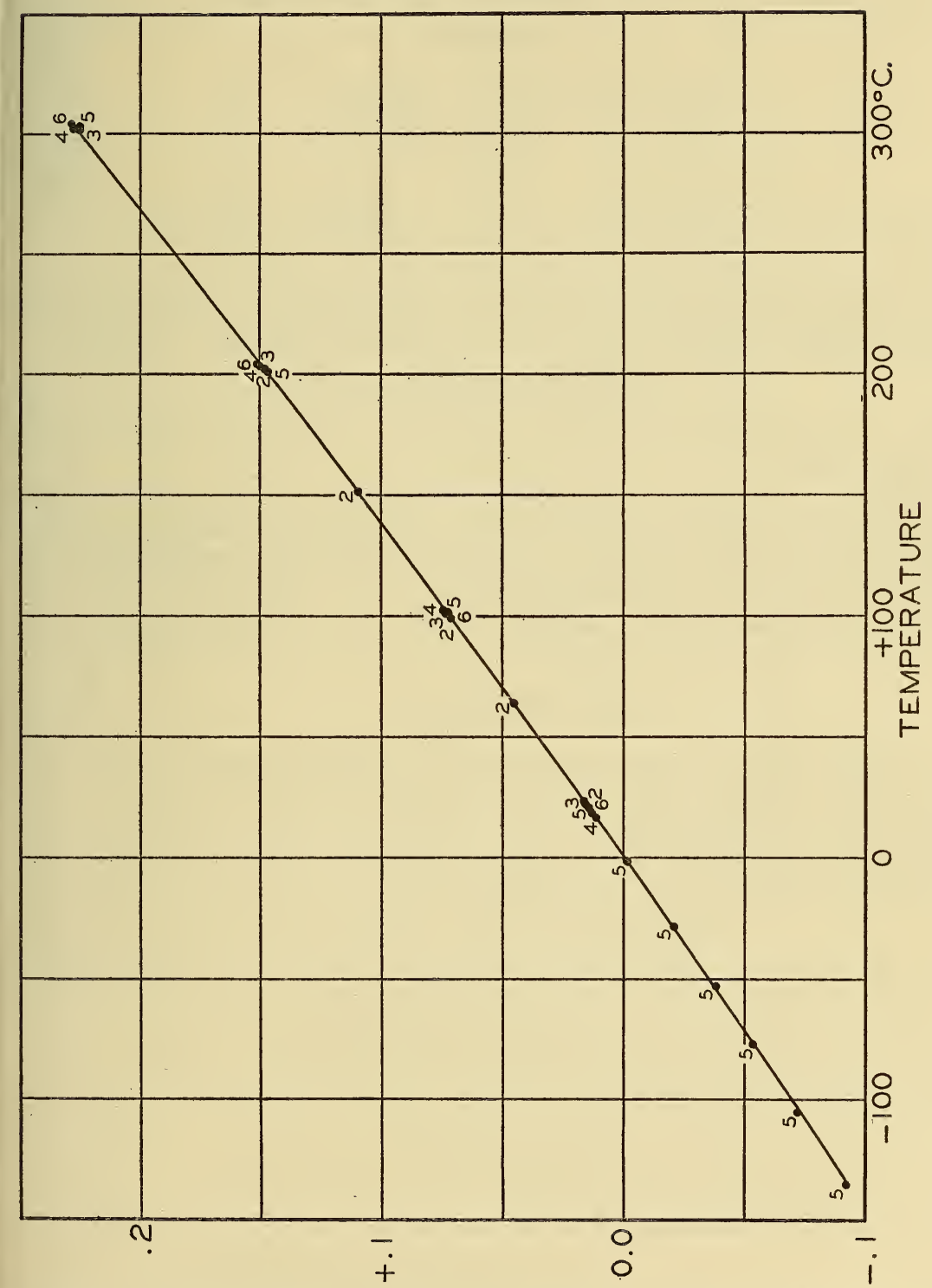

FIGURE 2.-Linear thermal expansion of columbium containing 0.93 percent tin and 0.26 percent iron (tests 2 to 6 , inclusive).

Curve represents equation (2). 
TABLE 3.-Average coefficients of linear expansion of columbium (computed from equation (2)).

\begin{tabular}{|c|c|c|c|}
\hline $\begin{array}{l}\text { Temperature } \\
\text { range }\end{array}$ & $\begin{array}{l}\text { Average } \\
\text { coefficient } \\
\text { of expan- } \\
\text { sion per } \\
\text { o. }\end{array}$ & $\begin{array}{l}\text { Temperature } \\
\text { range }\end{array}$ & $\begin{array}{l}\text { Average } \\
\text { coefficient } \\
\text { of expan- } \\
\text { sion per } \\
\text { o. }\end{array}$ \\
\hline $\begin{array}{r}0^{\circ} C_{-} \\
-135 \text { to }-100 \\
-100 \text { to }-75 \\
-75 \text { to }-50 \\
-50 \text { to }-25\end{array}$ & $\begin{array}{r}\times 10^{-6} \\
6.7 \\
6.8 \\
6.9 \\
6.9\end{array}$ & $\begin{array}{l}0^{\circ} C \\
100 \text { to } 150 \\
150 \text { to } 200 \\
200 \text { to } 300 \\
-100 \text { to } 0\end{array}$ & $\begin{array}{r}\times 10^{-6} \\
7.4 \\
7.6 \\
7.8 \\
6.9\end{array}$ \\
\hline $\begin{array}{rr}-25 \text { to } & 0 \\
0 \text { to } & +20 \\
+20 \text { to } & 60 \\
60 \text { to } & 100\end{array}$ & $\begin{array}{l}7.0 \\
7.1 \\
7.2 \\
7.3\end{array}$ & $\begin{array}{l}0 \text { to } 60 \\
0 \text { to } 100 \\
0 \text { to } 200 \\
0 \text { to } 300\end{array}$ & $\begin{array}{l}7.2 \\
7.2 \\
7.4 \\
7.5\end{array}$ \\
\hline
\end{tabular}

The following equation gives the instantaneous coefficient or rate of expansion at any temperature $t$ between $-135^{\circ}$ and $+305^{\circ} \mathrm{C}$.

$$
a_{t}=(7.06+0.00288 t) 10^{-6}
$$

This equation shows that the coefficient of expansion increases with temperature.

The data in table 1 indicate that columbium has the body-centered cubic lattice. It is therefore believed that many of the properties of columbium, such as thermal expansion, will be the same for a single crystal as for an isotropic aggregate.

WAShington, June 14, 1933. 